\title{
Age at the diagnosis and in the beginning of intervention from hearing impaired children, in a public Brazilian hearing health service
}

\section{Idade no diagnóstico e no início da intervenção de crianças deficientes auditivas em um serviço público de saúde auditiva brasileiro}

\section{Meliane Melina Pinto ${ }^{1}$, Jeziela Cristina Raimundo ${ }^{2}$, Alessandra Giannella Samelli ${ }^{3}$, Ana Claudia Martinho de Carvalho ${ }^{3}$, Carla Gentile Matas ${ }^{4}$, Gisele Munhoes dos Santos Ferrari ${ }^{5}$, Sérgio Garbi6, Mara Gândara ${ }^{6}$, Ricardo Ferreira Bento7.}

1) Specialist in Audiology. Phonoaudiologist.

2) Master. Phonoaudiologist from the Relistening Program-HCFMUSP.

3) Ph.D. Professor from the Phonoaudiology Course from FMUSP.

4) Free-Teacher. Professor from the Phonoaudiology Course from FMUSP.

5) Master. Phonoaudiologist from Relistening Program-HCFMUSP.

6) Otorhinolaryngologist Medic. Assistent from the Otorhinolaryngology Clinic from HCFMUSP.

7) Professor of Otorhinolaryngology from FMUSP.

Institution: Medical College from Universidade de São Paulo.

São Paulo / SP - Brazil.

Mailling Adress: Alessandra G. Samelli - Rua Cipotania, 51 - Cidade Universitária - São Paulo / SP - Brazil - Zip Code: 05360-160 - Telephone: (+55 11) 3091-8442 E-mail: alesamelli@usp.br

Article received in May 24th of 2011. Article approved in October $26^{\text {th }}$ o 2011.

\section{RESUMO}

Introdução: Quanto mais precoce o diagnóstico e intervenção da deficiência auditiva, menor será o impacto para o desenvolvimento das habilidades cognitivas, auditivas e de linguagem da criança.

Objetivo: Caracterizar a idade no diagnóstico e no início da intervenção da perda auditiva e o acompanhamento de crianças atendidas em um serviço público de saúde auditiva brasileiro - Espaço Reouvir do Hospital das Clínicas da Faculdade de Medicina da Universidade de São Paulo.

Método: Estudo retrospectivo com informações de 166 prontuários de crianças no que se refere a: gênero; etiologia, tipo, grau e lateralidade da deficiência auditiva; idade do diagnóstico e da adaptação do Aparelho de Amplificação Sonora Individual (AASI) e acompanhamento no serviço.

Resultados: A amostra foi composta por 56\% homens e $44 \%$ mulheres. A etiologia predominante foi a de origem multifatorial. A perda auditiva do tipo neurossensorial ocorreu em 88,6\% dos casos. O grau de perda auditiva moderado foi o de maior ocorrência $(30,7 \%)$, simetria entre as orelhas foi encontrada em $69,9 \%$ dos casos e perda auditiva unilateral em 2,4\%. A idade média no diagnóstico foi de 5,46 anos e na intervenção de 6,86 anos. Um total de 96,98\% das crianças já havia completado o processo de adaptação e 78,32\% permaneciam em acompanhamento.

Conclusão: O Programa Reouvir - HCFMUSP ainda recebe crianças, seja para o diagnóstico e/ou para a intervenção, de maneira tardia. Entretanto, ainda assim faz-se possível à realização do acompanhamento de um número significativo de crianças usuárias de AASI, possibilitando um processo de adaptação mais efetivo.

Palavras-chave: audição, auxiliares de audição, criança, perda auditiva.

\section{SUMMARY}

Introduction: The earlier the diagnosis and the intervention from the hearing impairment less will be the impact for the development of cognitive abilities, hearing and of speech from the child.

Objective: Characterize the age in the diagnosis and the beginning of intervention of the hearing loss and the accompaniment of the assisted children in a public Brazillian hearing health service - Espaço Reouvir from the Clinicas Hospital from the Medical School from the University of São Paulo.

Method: Retrospective study with information from 166 medical records from children regarding the: gender; etiology, type, degree and laterality of the hearing impairment; age in the diagnosis and adaptation of the Hearing aids (HA) and accompaniment in the service.

Results: The sample was composed by $56 \%$ men and $44 \%$ women. The prevailing etiology was from multifactorial origin. The hearing loss from the neurosensory type occurred in $88,6 \%$ of the cases. The degree of moderate hearing loss was the most frequent $(30,7 \%)$, symmetry in both ears was found in $69,9 \%$ of the cases and unilateral hearing loss in $2,4 \%$. The average age in the diagnosis was of 5,46 years and in the intervention was of 6,86 years. A total of $96,98 \%$ of children had already completed the process of adaptation and $78,32 \%$ still remained in the accompaniment.

Conclusion: The program Reouvir-HCFMUSP still receives children, both for diagnosis and or intervention in a late manner. However, still is possible the realization of the accompaniment of a significant number of users of the hearing aids, enabling a process of adaptation more effective.

Keywords: hearing, auxiliary of hearing, children, hearing loss. 


\section{INTRODUCTION}

The institution from the National Politics from Hearing Health by the ordinance MS/GM № 2.073 from 2004 states that the performance of the diagnosis and early intervention, in order to enable a better prognosis compared to the development of the oral language. In this scenario, the actions from health in the Basic Attention, in the Services of Attention to Hearing Health in the Middle and High Complexity (that compose the network from the Only System of Health - (SUS) allowing the access to: early identification of hearing impairment by means of newborn hearing screening, monitoring, including diagnosis, clinical treatment, use of the individual hearing aids (HA), following and speech therapy, besides ensuring the capability, technical support and orientation to the family (1).

Is a consensus that, the earlier the diagnosis of hearing impairment and the phonoaudiological interventions were made, less will be the impact of the hearing alteration to the development of the cognitive, hearing and speech abilities $(2,3,4)$.

However, the break between the suspect of the hearing deficiency by the family, and the audiologic diagnosis and the intervention remains too long. The first years of life are considered critical for the development of the speech and hearing abilities, since it is in this period that occur the peak of the process of maturation from the central auditory system, as well as neuronal plasticity from the hearing pathway $(4,5,6,7)$.

With the implementation of programs of newborn hearing screening, the professionals working in the area, have searched to decrease the break of time between the suspect of the hearing impairment and the medical intervention and the phonoaudiologist itself $(8,9)$. However, this goal still was not reached in all the country, once the law regulating the newborn hearing screening is too recent (in 08/02/2010 was sanctioned the Project of Law $n^{\circ} 3.842 / 97$ ), existing still a lot of challenges for its complete realization $(9,10)$.

To compose the process of speech therapy intervention, underlying to the diagnosis from the hearing impairment, the indication and selection from the electronic devices, between them the Hearing Aids (HA) and/or the Cochlear Implant, can be capable of minimize the impact of the hearing deficiency and to contribute for the development from the hearing and speech abilities (11).

The adaptation from these devices it is not a simple task and the challenges are constant during the process, because the linguistic and psychoacoustic needs from children are different of those expected to the adults carriers from hearing deficiency $(12,13)$. Besides, the periodic accompaniment is critical for the evaluation and the validation of the effective use of sound amplification and for the monitoring of hearing loss. The participation of the speech therapist and from the medic in this process is of extremely importance, once that these professionals assume the role of state, select, adapt and verify the adequate use and successful of HA (14).

Before these considerations, the objective of this study is to characterize the age in the diagnosis of the hearing loss and the beginning of the intervention, as the medical accompaniment and the phonoaudiologist of hearing impaired children attended in the Ambulatory of Hearing Health from the Clinical Hospital from Medical School from the Universidade de São Paulo - HCFMUSP (Relistening Program).

\section{METHOD}

The research was approved by the Ethical Committee for Analysis of Researches Projects (protocol no 0432/10) from HCFMUSP.

Is about a transversal and retrospective study, from data obtained at patients records from the Ambulatory of Hearing Health from HCFMUSP Relistening Program, accredited by Ordinance MS/GM n ${ }^{\circ}$ 2.073 , instituted by the Ministry of Health, in September $28^{\text {th }}$ of 2004 .

The Relistening Program is a service of attention to the hearing health of high complexity, being characterized by the specialized diagnostic and therapeutic attention, and by technical conditions, physical installation, equipments and human resources adequate to the attendance to people with risk or suspicious of hearing loss and people hearing impaired, articulated and integrated way with the regional and local system. Its objective is to perform the audiologic diagnosis in children, adults and elderly, treatment of the hearing loss, as well as the adaptation to the HA and hearing rehabilitation.

In what concernes the criteria of inclusion of the sample, were considered all the reports from the deaf children till the age of 12 years, attended in the Ambulatory of Hearing Health in the period from January of 2008 until February of 2011, and that used the HA and/or were in process of selection for the device.

This way, 166 children composed the sample of the study. Were used only the contained information in the 
records, in a way to conduct a survey from the following aspects:

- Gender;

- Etiology of the hearing impairment;

- Type, degree and laterality of the hearing impairment;

- Age of the child in the time of the diagnosis;

- Age of the child in the time of the intervention (adaptation to the HA);

- Medical accompaniment and phonoaudiologic in the service, after the adaptation to the HA.

Is noteworthy that, for the age diagnosed and the age in the beginning of the intervention, were considered, respectively, the first audiologic evaluation performed in the children and the initial moment of adaptation in the HA, apart from the place of performance from the procedures. The degree of the hearing loss was classified according to LLOYD and KAPLAN (1978).

This data were plotted and submitted to the statistical analysis, by means of the program Minitab. Were analyzed the descriptive measures average and standard deviation, as were used the tests chi-square and ANOVA. Was established a level of significance of $0,05(5 \%)$ and the breaks constituted were of $95 \%$ from statistical confidence.

\section{RESULTS}

The sample was composed by $56 \%$ of individuals from the male gender and $44 \%$ from the female gender, with significant prevalence from the male gender $(p=0,02$, chi-square). The etiology of the hearing loss predominant was from unknown origin $(42,78 \%)$, followed by multifactorial hearing losses, that involve children that presented many indicator of risk for hearing loss pre and perinatal associated $(18,07 \%)$. The other etiologies verified were: genetic; meningitis; syndromes; malformation from the outer ear, middle and/or inner; ototoxicity, among other causes (Image 1).

In regard to the hearing loss characteristics, the neurosensory type was present in $88,56 \%$ of the evaluated cases. The degree of hearing loss of most occurrence was the moderate, followed by deep, moderately severe, severe and light (Table 1). Was observed the symmetry between the ears in what concerns the degree from the hearing loss in $69,9 \%$ of cases ( $p<0,001$, chi-square test) and the presence of unilateral hearing loss was detected in only $2,4 \%$ from the subjects of the research ( $p<0,001$, chisquare).

In the total of evaluated children $(n=166)$, the average age in the diagnosis was of 5,46 years and in the intervention of 6,86 years, with a average break between the diagnosis and the intervention of 1,4 years (Table 2).

Considering only the laterality of the hearing loss (Table 3) or the degree of the hearing loss (Table 4), was observed that the diagnosis was late and to unilateral hearing losses and to hearing losses from light degree and moderately severe, both the comparison revealing statistically significant differences.

Can be observed still that most of the children $(96,98 \%)$ had already completed the process in the HA adaptation and most of the cases was still in medical accompaniment and phonoaudiologic at the service $(78,32 \%)$ (Table 5).

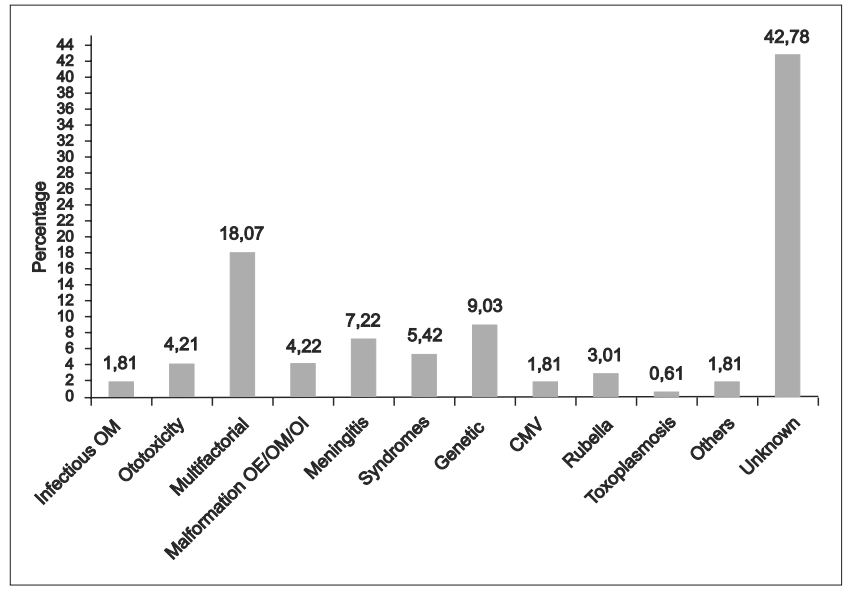

Image 1. Etiology from the hearing impairment.

Table I. Characteristics from the hearing loss (type and degree), considering the best ear.

\begin{tabular}{lcc}
\hline Type of the hearing loss & Best ear $(\mathrm{n})$ & $\%$ \\
\hline Conductive & 15 & 9,04 \\
Mixed & 4 & 2,40 \\
Neurosensory & 147 & 88,56 \\
\hline Total & 166 & 100 \\
\hline Degree fromthe hearing loss & Best ear $(\mathrm{n})$ & $\%$ \\
\hline Normal & 6 & 3,62 \\
Light & 9 & 5,42 \\
Moderate & 51 & 30,72 \\
Moderadately-severe & 30 & 18,07 \\
Severe & 24 & 14,45 \\
Profound & 46 & 27,72 \\
\hline Total & 166 & 100 \\
\hline
\end{tabular}


Table 2. Age diagnosed, age of intervention and gap between the diagnosis and intervention (in years).

\begin{tabular}{|c|c|c|c|c|}
\hline Process & $\begin{array}{c}\text { Average } \\
\text { (years) }\end{array}$ & $\begin{array}{l}\text { Standard } \\
\text { Deviation }\end{array}$ & $\begin{array}{c}\text { Minimum } \\
\text { (years) }\end{array}$ & $\begin{array}{c}\text { Maximum } \\
\text { (years) }\end{array}$ \\
\hline Age at the diagnosis & 5,46 & 3,09 & 0,16 & 15,59 \\
\hline Age atthe intervention & 6,86 & 3,16 & 0,92 & 17,23 \\
\hline $\begin{array}{l}\text { Gap betweenthe } \\
\text { diagnosesand } \\
\text { intervention }\end{array}$ & 1,40 & 1,93 & 0,00 & 12,02 \\
\hline
\end{tabular}

Table 4. Age at the diagnosis (in years) for hearing losses from light to moderately-severe compared to hearing losses severe and profound.

\begin{tabular}{lcc}
\hline Process Average & $\begin{array}{c}\text { Standard } \\
\text { Deviation }\end{array}$ \\
\hline
\end{tabular}

\begin{tabular}{llll}
\hline $\begin{array}{l}\text { Age atthe diagnosisfrom } \\
\text { hearing lossfrom light }\end{array}$ & & & \\
tomoderately-severe & 6,46 & 3,06 & $<.000$ I \\
$\begin{array}{l}\text { Age fromthe diagnosisfrom } \\
\text { hearinglossfromsevere to } \\
\text { profound }\end{array}$ & & & \\
\hline
\end{tabular}

Subtitle: ANOVA

\section{DISCUSSION}

The hearing deficiency can bring great disturbances to the global development of the child, generating great impact under the community, whether being from the economic point of view or psychosocial. The early diagnosis and the immediate intervention are essential to ensure the hearing impaired children a better development from the cognitive, hearing and speech abilities, once this is a highly disabling deficiency, considering their effects in the communication $(3,4)$.

This study has as objective characterize the age in the diagnosis of hearing loss and in the beginning of the intervention, as the medical and phonoaudiologic monitoring from hearing impaired children attended in the Ambulatory of Hearing Health from HCFMUSP (Relistening Program), because of the evidence that the indentification and early intervention are essential to a better global development from the child.

According to the World Health Organization(WHO), 90\% of all children with hearing impairment capable to damage the hearing and speech abilities ( $>40 \mathrm{~dB}$ ) live in countries that are developing (15), making the questionnaire
Table 3. Age at the diagnosis (in years) for uni and bilateral hearing losses.

\begin{tabular}{lccc}
\hline Process & Average & $\begin{array}{c}\text { Standard } \\
\text { Deviation }\end{array}$ & p-value \\
\hline $\begin{array}{l}\text { Age from diagnosesfrom } \\
\text { unilateral hearing loss }\end{array}$ & 6,80 & 3,14 & $<.0001$ \\
$\begin{array}{l}\text { Age from diagnosis of } \\
\text { Bilateral hearing loss }\end{array}$ & 5,42 & 3,09 &
\end{tabular}

Subtitle: ANOVA

Table 5. Process of adaptation from HA/ follow-up in the service.

\begin{tabular}{lcc}
\hline Process & $\mathrm{n}$ & $\%$ \\
\hline Completeadaptation & $|6|$ & 96,98 \\
Inexperience & 5 & 3,02 \\
\hline Total & 166 & 100 \\
\hline Follow-up & $\mathrm{n}$ & $\%$ \\
\hline Remains infollow-up & 130 & 78,32 \\
Missed the last consult offollow-up & 20 & 12,05 \\
Abandonservice & 12 & 7,22 \\
Forwardedtocochlearimplant & 4 & 2,41 \\
\hline Total & 166 & 100 \\
\hline
\end{tabular}

of diagnosis and early intervention even more delicate in those regions.

Previous studies point that the average age of identification of the hearing loss and the absence of newborn hearing screening programs is around 2 years and a half to 3 years, which is considered late (8), taking in consideration the recommendations from the scientific community in what concerns the adaptation to electronic devices before the six months old (16). In countries in development, the situation is even more serious, the age described in the identification of the hearing loss ranging from 2 to 7 years (17).

In the present research, the sample was constituted by children until 12 years, being $56 \%$ from the male gender and $44 \%$ from the female gender, with differences statistically significant for that distribution. This finding agrees with another study from the literatures, which also verified a greater number of individuals from the male gender with hearing impairment among the deaf in Rio de Janeiro (18), and corroborate other investigations that verified a larger number of boys among the children with risk of hearing loss $(19,20)$.

The etiology of the predominant hearing losses was from unknown origin, followed by hearing losses of 
multifactorial etiologies, that involve many indicators of risk for hearing losses associate to pre and perinatal. The WHO emphasized that genetic factors can be responsible for $30 \%$ from the prelingual hearing losses, while $20 \%$ can be related to problems pre and perinatal (21). The verified percentage in the present study of hearing losses involving indicators of pre and perinatal risks (18,07\%) approached from the values described by the WHO.

As many of participating children were not submitted to genetic studies, is possible that a parto $f$ the hearing losses from unknown etiologies can be related to genetic factors.

According to the characteristics from the hearing loss, was observed a greater occurrences of hearing losses from the neurosensory, bilateral and symmetric kind. Regarding the degree, the hearing losses from lighter degree and moderately severe represented $54,21 \%$ of the evaluated children. The results showed that the laterality and the degree from the hearing loss can influence at the age of diagnosis from the hearing loss, in other words, unilateral hearing losses and/or from light degree and moderately-severe are diagnosed more late than the hearing losses bilateral and/or from severe to profound degree.

This findings can be justified from the imposed limitations for the hearing loss taking into consideration the degree, ie, children with severe or profound hearing losses, frequently present a bigger commitment regarding the development of speak and speech, being the hearing alteration noticed earlier than the alteration from light to moderately severe degree and/or unilateral, which can remain imperceptible to the parents for a longer period $(20,22,23)$.

When were analyzed all the attended children in the service, independent from the hearing loss characteristics, was verified the average age in the diagnosis was from 5,46 years with a middle gap between the diagnosis and the intervention of 1,4 years. This data showed that the average age among the children that initiate the use of HA was of approximately 7 years, agreeing with the literature findings that come from countries in development (24).

Is important to highlight that the checked panorama for the population in question, is referring to a previous period from the implementation of universal newborn hearing screening, since that the federal law that instituted this procedure was sanctioned recently, in August from 2010. However, this fact emphasize a important priority for countries in development, that is establish and to do the universal newborn hearing screening, ensuring a infrastructure that ensure not only the early identification of the hearing losses, but also the following and the access to services of appropriate intervention for the children and its family, optimizing the process for the development from the hearing and speech abilities $(4,8)$.

The data from the present study showed that, even with age in the diagnosis and beginning of the intervention occurring later, most of the attended children at the service in question have already completed the process of adaptation from the HA and remains in medical and phonoaudiologic accompaniment in the referred service.

Such finding reinforces the importance from the process of periodic accompaniment to validate the effective use of the hearing aid, as well as to the monitoring of the hearing loss (17). The performed evaluations through the following of those kids are from fundamental importance for the verification of the hearing performance obtained by means of using the HA, and also enable to observe the process of development of the oral language and trace the therapeutic goals for each child. Besides, this follow-up data, available to all professionals involved in the attendance, bring concrete evidences of the repercussions of the treatment, favoring the exchanges of information between different institutions and professionals.

It should be emphasized that, this data show the panorama from a Service of Attention to the Hearing Health from High Complexity in the city of São Paulo and, because of the differences and inherent characteristics to every state and/or city, may differ from other services.

\section{CONCLUSION}

The present study verified that the Ambulatory of Hearing Health from HCFMUSP - Relistening Program still receives children, whether for the diagnosis and/or for the intervention, in a later way, damaging very much the development from the hearing, cognitive and speech abilities from those children. However, still is possible the realization of the follow-up from a significant number of children users from the HA, that integrate the ambulatory, making, therefore a process of adaptation much more effective.

\section{BibLIOGRAPHIC REFERENCES}

1. GM 2073/04 de 28 de setembro de 2004. Disponível em: http://portalweb05.saude.gov.br/portal/sas/mac/ area.cfm? id_area $=848$ ou http://dtr2001.saude.gov.br/sas/ PORTARIAS/Port2004/GM/GM-2073.htm

2. Yoshinaga-Itano C. From screening to early identification and intervention: discovering predictor to successful 
outcomes for children with significant hearing loss. J Deaf Stud Deaf Educ. 2003, 8(1):11-30.

3. Theunissen M, Swanepoel DW. Early hearing detection and intervention services in the public health sector in South Africa. Int J Audiol. 2008, 47 (Suppl. 1): S23-S29.

4. Yoshinaga-Itano C, Thomson V. The work of the Village: Creating a new world for children with hearing loss and their families. Int J Audiol. 2008, 47 (Suppl. 1): S14-S22.

5. Azevedo MF. Avaliação audiológica no primeiro ano de vida. Em: Lopes Filho O. (Ed). Tratado de Fonoaudiologia. 1 ํㅡㄹ. São Paulo: Roca; 1997. pp 239-263.

6. Roslyng-Jensen AMA. Importância do diagnóstico precoce na deficiência auditiva. Em: Lopes Filho O. (Ed). Tratado de Fonoaudiologia. $1^{\underline{a}}$ Ed. São Paulo: Roca; 1997 pp. 297-309.

7. Nóbrega M, Weckx LLM, Juliano Y, Novo NF. Aspectos diagnósticos e etiológicos da deficiência auditiva em crianças e adolescentes. Rev Paul Pediatr. 1998, 16(1):28-43.

8. Shulman S, Besculides M, Saltzman A, Ireys H, White KR, Forsman I. Evaluation of the universal newborn hearing screening and intervention program. Pediatrics. 2010, 126(Suppl 1):S19-S27.

9. Taha AA, Pratt SR, Farahat TM, Abdel-Rasoul GM, Albtanony MA, Elrashiedy ALE, Alwakeel HR, Zein A. Prevalence and risk factors of hearing impairment among primary-school children in Shebin El-Kom District, Egypt. Am J Audiol. 2010, 19:46-60.

10. Pádua FGM, Marone S, Bento RF, Carvalho RMM, Durante AS, Soares JC, Barros JC, Leoni CR. Triagem Auditiva Neonatal: um desafio para sua implantação. Arq Otorrinolaringol. 2005, 3(9):190-4.

11. Russ SA, Dougherty D, Jagadish P. Accelerating evidence into practice for the benefit of children with early hearing loss. Pediatrics. 2010, 126(Suppl 1):S7-S18.

12. Almeida K, Momensohn-Santos TM. Seleção e adaptação de próteses auditivas em crianças. Em: Almeida K, Iório MCM (ed). Próteses auditivas e fundamentos teóricos e aplicações clínicas. $2^{a}$ ed. São Paulo: Editora Lovise, 2003 , pp.358-384.

13. Beauchaine KL, Donaghy KF. Amplification selection considerations in the pediatric population. In: Bess FH, Gravel JS, Tharpe AM. (eds.) Amplification for Children with Auditory Deficits. Nashville, TN: Bill Wilkerson Center Press, 1996, pp. 145-160.
14. Teixeira CF. Estudo avaliativo da política de atenção à saúde auditiva: estudo de caso em Pernambuco. Recife, 2007, p. 159, (Tese de Doutorado em Saúde Pública - Centro de Pesquisas Aggeu Magalhães, Fundação Oswaldo Cruz).

15. Swanepoel DW, Störbeck C. EHDI Africa: Advocating for infants with hearing loss in Africa. Int J Audiol. 2008, 47(Suppl. 1):S1-S2.

16. Joint Committee on Infant Hearing. Year 2007 Position Statement: principles and guideslines for early hearing detection and intervention programs. Pediatrics. 2007, 120(4):898-921.

17. Olusanya BO, Newton VE. Global burden of childhood hearing impairment and disease control priorities for developing countries. Lancet. 2007, 369:1314-1317.

18. Silva EJC, Llerena JrJC, Cardoso MHCA. Estudo seccional descritivo de crianças com deficiência auditiva atendidas no Instituto Nacional de Educação de Surdos, Rio de Janeiro, Brasil. Cad Saúde Pública. 2007, 23(3):627-636.

19. Manfredi AKS, Santos CB. Intervenção Fonoaudiológica juntoàs mães ou responsáveis por Recém-Nascidos de Risco para Deficiência Auditiva, precocemente detectada. Medicina. 2002, 35:70-7.

20. Gierek T, Gwózdz-Jezierska M, MarkowskiJ, Witkowska $\mathrm{M}$. The assessment of hearing organ of school children in Upper Silesia region. Int J Ped Otorhinolaryngol. 2009, 73:1644-1649.

21. Smith AW. WHO activities for prevention of deafness and hearing impairment in children. Scand Audiol. 2001, 30(Suppl 53):93-100.

22. CzechowiczJA, Messner AH, Alarcon-Matutti E, Alarcon J, Quinones-Calderon G, Montano S, Zunt JR. Hearing impairment and poverty: The epidemiology of ear disease in Peruvian schoolchildren. Otolaryngol Head Neck Surg. 2010, 142:272-277.

23. Cone BK, Wake M, Tobin S, Poulakis Z, Richards FW. SlightMildsensorineural hearing lossin children: Audiometric, clinical, and risk factor profiles. Ear Hear. 2010, 31(2):201-212.

24. Olusanya BO. Hearing impairment prevention in developing countries: Making things happen. Int J Ped Otorhinolaryngol. 2000, 55:167-171. 